\title{
Correction: Outcomes of infants born at 22-27 weeks' gestation in Victoria according to outborn/ inborn birth status
}

Boland RA, Davis PG, Dawson JA, et al. Outcomes of infants born at 22-27 weeks' gestation in Victoria according to outborn/inborn birth status (Archives of Disease in Childhood - Fetal and Neonatal Edition 2017;102:F153-F161).

The authors have identified an error in their paper. Table 3 reports the univariable and adjusted OR for a range of serious morbidities, comparing outborn with inborn infants. The authors incorrectly reported there was no statistically significant difference in the risk of Grade 3 or 4 intraventricular haemorrhage (IVH) comparing outborn with inborn infants, when in fact there was. The error resulted from incorrect syntax entered into STATA. Hence the adjusted OR, 95\% confidence intervals and p-value are incorrect for the outcome of Grade 3 or 4 intraventricular haemorrhage. They have therefore amended table 3 , and would like to alert readers to other corrections in the main body of the paper. The same problem occurred with Grade 1 or 2 intraventricular haemorrhage, but no conclusions were affected by this error - just the data in table 3 . The amendments are outlined below.

\begin{tabular}{lllllll}
\hline & $\begin{array}{l}\text { Outborn } \\
\mathbf{n}=49\end{array}$ & $\begin{array}{l}\text { Inborn } \\
\mathbf{n}=396\end{array}$ & $\begin{array}{l}\text { Univariable } \\
\text { OR }(95 \% \mathrm{Cl})\end{array}$ & $\mathbf{P}=$ & $\begin{array}{l}\text { Adjusted OR } \\
(95 \% \mathrm{Cl})\end{array}$ & $\mathrm{P}=$ \\
\hline Grade 1 or 2 & $13(27 \%)$ & $96(24 \%)$ & $1.13(0.57$ to 2.21$)$ & 0.73 & $1.11(0.56$ to 2.23$)$ & 0.76 \\
Grade 3 or 4 & $10(20 \%)$ & $42(11 \%)$ & $2.16(1.01$ to 4.64$)$ & 0.048 & $2.99(1.28$ to 6.98$)$ & 0.012 \\
\hline
\end{tabular}

Please also see the table below for corrections in the paper in relation to Grade 3 or 4 IVH risk.

\begin{tabular}{|c|c|c|}
\hline Section/Page No & Current text & Amendments \\
\hline $\begin{array}{l}\text { Abstract, } \\
\text { results section }\end{array}$ & $\begin{array}{l}\text { There were no significant differences in rates } \\
\text { of necrotising enterocolitis, intraventricular } \\
\text { haemorrhage, retinopathy of prematurity... }\end{array}$ & $\begin{array}{l}\text { There were no significant differences in rates } \\
\text { of necrotising enterocolitis, retinopathy of } \\
\text { prematurity }\end{array}$ \\
\hline $\begin{array}{l}\text { Abstract, } \\
\text { results section }\end{array}$ & $\begin{array}{l}\text { Outborn infants had an increased risk of cystic } \\
\text { periventricular leukomalacia (cPVL) compared with } \\
\text { inborn infants }(12.2 \% \text { vs } 2.8 \%) \text { respectively; aOR } \\
5.34,95 \% \mathrm{Cl} \\
1.84 \text { to } 15.54, \mathrm{p}=0.002 \text {. }\end{array}$ & $\begin{array}{l}\text { Outborn infants had increased risks of grade } 3 \text { or } 4 \\
\text { intraventricular haemorrhage (aOR } 2.99, p=0.012 \text { ) } \\
\text { and cystic periventricular leukomalacia (aOR } 5.34 \text {, } \\
95 \% \mathrm{Cl} 1.84 \text { to } 15.54, p=0.002) \text {. }\end{array}$ \\
\hline $\begin{array}{l}\text { Morbidity section, } \\
\text { paragraph } 1\end{array}$ & $\begin{array}{l}\text { There were no significant differences in rates } \\
\text { of NEC (any stage) IVH (any grade), ROP, the } \\
\text { combined outcome of ...... }\end{array}$ & $\begin{array}{l}\text { There were no significant differences in rates } \\
\text { of NEC (any stage), Grade } 1 \text { or } 2 \text { IVH, ROP, the } \\
\text { combined outcome of... }\end{array}$ \\
\hline $\begin{array}{l}\text { Morbidity section, } \\
\text { paragraph } 1\end{array}$ & $\begin{array}{l}\text { However, outborn infants has an increased risk of } \\
\text { PVL compared with inborns. }\end{array}$ & $\begin{array}{l}\text { However, outborn infants had increased risks of } \\
\text { Grade } 3 \text { and } 4 \text { IVH and PVL compared with inborn } \\
\text { infants. }\end{array}$ \\
\hline $\begin{array}{l}\text { Discussion, } \\
\text { paragraph } 6\end{array}$ & $\begin{array}{l}\text { We also found outborns admitted to NICU had } \\
\text { similar risks of serious morbidity compared with } \\
\text { inborns, with the exception of PVL }\end{array}$ & $\begin{array}{l}\text { We also found outborns admitted to NICU had } \\
\text { similar risks of serious morbidity compared with } \\
\text { inborns, with the exceptions of Grade } 3 \text { or } 4 \text { IVH } \\
\text { and PVL }\end{array}$ \\
\hline $\begin{array}{l}\text { Discussion, } \\
\text { F4 paragraph } 6\end{array}$ & $\begin{array}{l}\text { The significantly higher risk of PVL in outborns was } \\
\text { concerning and warrants further investigation. }\end{array}$ & $\begin{array}{l}\text { The significantly higher risks of Grade } 3 \text { or } 4 \text { IVH } \\
\text { and PVL in outborns were concerning and warrant } \\
\text { further investigation. }\end{array}$ \\
\hline
\end{tabular}

(C) Author(s) (or their employer(s)) 2020. No commercial re-use. See rights and permissions. Published by BMJ.

Arch Dis Child Fetal Neonatal Ed 2020;0. doi:10.1136/fetalneonatal-2015-310313corr1

Check for updates 